\title{
Acrodermatitis enteropathica with ocular manifestations
}

\author{
Deepsekhar Das 주, Aishwarya Rathod, Sujeeth Modaboyina 지 , Sahil Agrawal
}

Dr. Rajendra Prasad Centre for Ophthalmic Sciences, All India Institute of Medical Sciences, New Delhi, India

\section{Correspondence to} Dr Sahil Agrawal; agrawalsahil03.acad@gmail. com

Accepted 17 July 2021
Check for updates

(c) BMJ Publishing Group Limited 2021. No commercial re-use. See rights and permissions. Published by BMJ.

To cite: Das D, Rathod A Modaboyina $S$, et al. BMJ Case Rep 2021:14:e244545. doi:10.1136/bcr-2021244545

\section{DESCRIPTION}

Acrodermatitis enteropathica is a rare autosomal recessive metabolic disease with occasional ocular manifestations. It was first described by Brandt in 1936 and named so by Danbolt. ${ }^{1}$ It occurs worldwide with an estimated incidence of 1 per 500000 children with no apparent predilection for race or sex. $^{2}$

A 12-year-old boy presented with reports of chronic diarrhoea, skin lesions, photophobia and purulent discharge from both eyes for a week. Family history was insignificant. On examination, he had acral psoriasis-like dermatitis (figure 1A,B) with cicatricial alopecia (figure 1C). On ophthalmological examination, bilateral cicatricial lagophthalmos with ciliary and eyebrow madarosis was found (figure 1D). The skin over the eyelids was shiny, scaly and hyperpigmented. Ocular surface had conjunctival xerosis and moderate dry eye disease. He had reduced blood levels of zinc $(42 \mu \mathrm{g} / \mathrm{dL})$, and genetic analysis revealed a mutation in the SLC39A4 gene. He was diagnosed with a case of congenital acrodermatitis enteropathica.

It is a disorder of zinc metabolism with congenital and acquired forms characterised by dermatological manifestations (characteristically vesiculobullous when active), mucosal inflammation (commonly conjunctivitis) and steatorrhea. ${ }^{3}$ Conjunctivitis, blepharitis and photophobia are the most common affections seen in these cases. The upper part of the cornea is also known to have a band-shaped opacity concentric to the limbus with radiating lines from it. ${ }^{4}$ The disorder is caused by a mutation in the SLC39A4 gene on chromosome 8q24.3 encoding for a transmembrane protein, which uptakes zinc Zip4 (acts as a transporter). ${ }^{5}$ The metabolism of protein, carbohydrate and vitamins require zinc as an essential trace element, as it is necessary for the proper functioning of all cells. ${ }^{6}$ Zinc replacement therapy should be started at $3 \mathrm{mg} / \mathrm{kg} /$ day of elemental zinc (there is $50 \mathrm{mg}$ of elemental zinc per $220 \mathrm{mg}$ zinc sulfate) in acrodermatitis enteropathica. Clinical improvement is seen within days to weeks, quite rapidly, typically even before a significant change in serum zinc levels. ${ }^{7}$ Zinc most characteristically causes gastric irritation with nausea, vomiting and gastric haemorrhage. Multisystem organ failure, endangering life, may be caused by large accidental doses of zinc. ${ }^{8}$

Our patient was started on oral zinc gluconate 3 $\mathrm{mg} / \mathrm{kg}$ and vitamin A supplementation with monitoring of zinc plasma levels every 3 months and preservative-free lubricants for ocular relief. The
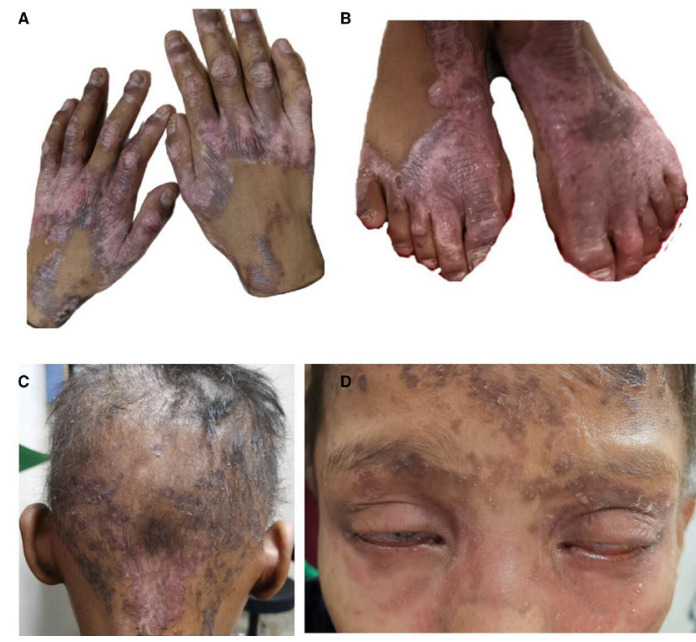

Figure 1 Clinical photograph of the patient showing erythema, scaling and crusting over hand and feet along with nail dystrophy $(A, B)$, cicatricial alopecia over scalp (C) and bilateral cicatricial lagophthalmos with ciliary and eyebrow madarosis (D).

patient improved drastically within a week and was kept on lifelong zinc therapy.

Diagnosis of acrodermatitis enteropathica is based on clinical symptoms (triad of periorificial dermatitis, aloplecia and diarrhoea) and low plasma levels of zinc, with a rapid clinical response to supplementation as a confirmation of the disease. Early diagnosis is essential for preventing complications both ocular and systemic.

\section{Patient's perspective}

I pray no one else gets such a disease. With treatment I am much better and relieved of my eye problems.

\section{Learning points}

Although acrodermatitis enteropathica is treatable, early recognition and prompt start of treatment are extremely important.

- Supplementation of zinc and serum level monitoring every 3 months with lubricants for ocular relief is the key to ophthalmological treatment 
Contributors DD was the primary point of contact and the chief surgeon. AR helped in data collection, literature review. SM helped in the primary drafting of the manuscript. SA did a critical review and final approval of the manuscript.

Funding The authors have not declared a specific grant for this research from any funding agency in the public, commercial or not-for-profit sectors.

Competing interests None declared.

Patient consent for publication Obtained.

Provenance and peer review Not commissioned; externally peer reviewed.

\section{ORCID iDs}

Deepsekhar Das http://orcid.org/0000-0002-4446-0274

Sujeeth Modaboyina http://orcid.org/0000-0002-1306-5722

Sahil Agrawal http://orcid.org/0000-0001-6667-249X

\section{REFERENCES}

1 Brandt TH. Dermatitis in children with disturbances of the general condition and the absorption of food elements. Acta Derm Venereol 1936:17:1.

2 Van Wouwe JP. Clinical and laboratory assessment of zinc deficiency in Dutch children. A review. Biol Trace Elem Res 1995:49:211-25.

3 Van Wouwe JP. Clinical and laboratory diagnosis of acrodermatitis enteropathica. Eur J Pediatr 1989;149:2-8.

4 Vasantha K, Kannan KA. Acrodermatitis enteropathica--a case report. Indian J Ophthalmol 1989;37:197-8.

5 Küry S, Dréno B, Bézieau S, et al. Identification of Slc39a4, a gene involved in acrodermatitis enteropathica. Nat Genet 2002;31:239-40.

6 Maverakis E, Fung MA, Lynch PJ, et al. Acrodermatitis enteropathica and an overview of zinc metabolism. J Am Acad Dermatol 2007;56:116-24.

7 Blom I, Jameson S, Krook F, et al. Zinc deficiency with transitory acrodermatitis enteropathica in a boy of low birth weight. Br J Dermatol 1981;104:459-64.

8 Brocks A, Reid H, Glazer G. Acute intravenous zinc poisoning. Br Med J 1977;1:1390-1.

Copyright 2021 BMJ Publishing Group. All rights reserved. For permission to reuse any of this content visit https://www.bmi.com/company/products-services/rights-and-licensing/permissions/

BMJ Case Report Fellows may re-use this article for personal use and teaching without any further permission.

Become a Fellow of BMJ Case Reports today and you can:

- Submit as many cases as you like

- Enjoy fast sympathetic peer review and rapid publication of accepted articles

- Access all the published articles

Re-use any of the published material for personal use and teaching without further permission

Customer Service

If you have any further queries about your subscription, please contact our customer services team on +44 (0) 2071111105 or via email at support@bmj.com.

Visit casereports.bmj.com for more articles like this and to become a Fellow 